\section{Band 28, Heft 4, August 2012}

\section{Editorial}

230 Funktionelle Dickdarmchirurgie

Kutup, A.; Keller, J.; Layer, P.; Izbicki, J.R. (Hamburg)

Hauptthema

231 Systematik und Diagnostik der funktionellen Obstipation und Slow Transit Constipation

Frieling, T. (Krefeld)

237 Systematik und Diagnostik des obstruktiven Defäkationssyndroms

Fürst, A.; Keßler, A.; Liebig-Hörl, G. (Regensburg)

243 Medikamentös-konservative Therapieoptionen der Obstipation bei primären Funktionsstörungen des Kolons - vom Reizdarmsyndrom bis zur Slow Transit Constipation Keller, J.; Layer, P. (Hamburg)

250 Sekundäre Form der Obstipation aufgrund von medikamentösen Nebenwirkungen und endokrinen, neurologischen und psychiatrischen Erkrankungen medikamentös-konservative Therapieoptionen Pehl, C. (Vilsbiburg)

255 Indikationen und Therapieoptionen aus chirurgischer Sicht bei der Kolontransitstörung Zehler, O.; Kutup, A. (Hamburg)

260 Indikationen und chirurgische Therapieoptionen beim obstruktiven Defäkationssyndrom

Schwandner, O. (Regensburg)

Interdisziplinäres Gespräch

267 Funktionelle Dickdarmchirurgie Matzel, K. (Erlangen) (Gesprächsleiter)

Originalarbeit

275 Adipositasinzidenz bei Patientinnen mit analer Inkontinenz

Bussen, D.; Herold, A.; Bussen, S. (Mannheim)
Vol. 28, Issue 4, August 2012

\section{Editorial}

230 Functional Surgery of the Colon

Kutup, A.; Keller, J.; Layer, P.; Izbicki, J.R. (Hamburg)

Main Topic

231 Characterization and Diagnostics of Functional Constipation and Slow Transit Constipation Frieling, T. (Krefeld)

237 Systematic and Diagnostic Procedures of the Obstructed Defecation Syndrome Fürst, A.; Keßler, A.; Liebig-Hörl, G. (Regensburg)

243 Conservative Treatment Options for Constipation due to Primary Dysfunctions of the Colon - from Irritable Bowel Syndrome to Slow Transit Constipation

Keller, J.; Layer, P. (Hamburg)

250 Secondary Constipation due to Drug Intake and Endocrine, Neurological, and Psychiatric Diseases Conservative Therapeutic Options Pehl, C. (Vilsbiburg)

255 Indications and Therapeutic Options for Slow Transit Constipation from the Surgical Point of View

Zehler, O.; Kutup, A. (Hamburg)

260 Indications and Surgical Strategies in Obstructed Defecation Syndrome

Schwandner, O. (Regensburg)

Interdisciplinary Discussion

267 Functional Surgery of the Colon

Matzel, K. (Erlangen) (Discussion Leader)

Original Article

275 Incidence of Obesity in Female Patients with Fecal Incontinence

Bussen, D.; Herold, A.; Bussen, S. (Mannheim)

\section{KARGER}

Fax +497614520714

Information@Karger.de

www.karger.com
(C) 2012 S. Karger GmbH, Freiburg 


\section{Band 28, Heft 4, August 2012}

Fallbericht

280 Hepatozelluläres Karzinom statt fokal noduläre Hyperplasie - ein Fallbericht

Schulze, S.-E.; Guthoff, A.; Quaas, A.; Nashan, B.; Lohse, A.W. (Hamburg)

283 News / Ticker

285 Tagungen und Kongresse

288 Hinweise für Autoren

274 Impressum
Vol. 28, Issue 4, August 2012

Case Report

280 Hepatocellular Carcinoma instead of Focal Nodular Hyperplasia - a Case Report

Schulze, S.-E.; Guthoff, A.; Quaas, A.; Nashan, B.; Lohse, A.W. (Hamburg)

283 News / Ticker

285 Meetings and Conferences

288 Guidelines for Authors

274 Imprint

\section{KARGER}

(C) 2012 S. Karger GmbH, Freiburg

Fax +497614520714 